

\title{
Diagnoza logopedyczna noworodka i niemowlęcia
}

\begin{abstract}
Ewa Gacka, Diagnoza logopedyczna noworodka i niemowlęcia [The speechtherapy diagnosis of a new-born child and an infant]. Interdyscyplinarne Konteksty Pedagogiki Specjalnej, nr 14, Poznań 2016. Pp. 13-28. Adam Mickiewicz University Press. ISSN 2300-391X

The issues of the speech-therapy early intervention were brought up in the article. An outline of the speech-therapy diagnosis of the newborn child and the infant was presented, and also the chosen tools were introduced in order to make the speechtherapy assessment of those babies
\end{abstract}

KEY WORDS: the early intervention, the speech-therapy diagnosis, a new-born child, an infant.

\section{O istocie wczesnej interwencji logopedycznej}

Zagadnienia związane $\mathrm{z}$ wczesną interwencją pozostają $\mathrm{w}$ sferze zainteresowań medycyny, psychologii, pedagogiki, a także logopedii. W teorii i praktyce logopedycznej pod tym pojęciem najczęściej rozumie się oddziaływania skierowane na najmłodsze dzieci, od momentu narodzin. Wczesna interwencja logopedyczna dotyczy dzieci z zaburzeniami rozwojowymi, w tym mogącymi zakłócić rozwój mowy (np. z zespołem Downa, niedosłuchem/głuchotą, rozszcze- 
pem wargi i/lub podniebienia, mózgowym porażeniem dziecięcym) oraz dzieci ryzyka wystąpienia nieprawidłowości w zakresie komunikacji językowej (np. wcześniaków, dzieci hipotroficznych czy z obciążonym wywiadem okołoporodowym). W założeniach pilotażowego, rządowego programu realizowanego w latach 2005-2007 $\mathrm{w}$ ramach wczesnego wspomagania rozwoju (obejmującego także wczesną interwencję, w tym pomoc logopedyczną) jej odbiorcy zostali zdefiniowani jako dzieci zagrożone niepełnosprawnością i niepełnosprawne, w wieku od urodzenia do siódmego roku życia ${ }^{1}$.

W literaturze przedmiotu zwraca się uwagę na inne, szersze znaczenie terminu, zgodnie z którym wczesna interwencja logopedyczna jest postrzegana także jako działania podejmowane wobec osób dorosłych, w tym starych ${ }^{2}$. W tych przypadkach postępowanie logopedyczne zmierza do przeciwdziałania językowym skutkom schorzeń w ich początkowym stadium lub spowolnienia niekorzystnych, a nieuchronnych - z punktu widzenia współczesnej nauki - zmian dotyczących komunikacji językowej, jak ma to miejsce np. u osób z chorobą Parkinsona czy otępieniem alzheimerowskim. Słuszne wydaje się stwierdzenie Jacka Błeszyńskiego, że wczesna interwencja to każde szybko podejmowane działanie wobec osób z grupy zagrożonej wystąpieniem nieprawidłowości lub wobec pacjentów, u których wystąpiły pierwsze symptomy zaburzeń, bez względu na ich wiek³.

Podmiotami wczesnej interwencji są zarówno sami pacjenci (dzieci i dorośli), jak i ich rodziny. Takie ujęcie odbiorców wczesnej pomocy znajduje oparcie w systemowej teorii rodziny ${ }^{4}$. Pacjent jest

${ }_{1}$ Wczesna, wielospecjalistyczna, kompleksowa, skoordynowana i ciagła pomoc dziecku zagrożonemu niepetnosprawnością lub niepetnosprawnemu oraz jego rodzinie, https://www. nfz.rzeszow.pl/files/dokumenty/63_2005_zal.pdf [dostęp: 19.09.2016].

2 D. Pluta-Wojciechowska, Wczesna interwencja logopedyczna - moda, postulat czy konieczność, [w:] Wczesna interwencja w logopedii, red. J.J. Błeszyński, D. Baczała, Harmonia Universlias, Gdańsk 2015, s. 17-29; J.J. Błeszyński, Wczesna interwencja - różne podejścia, ujęcia, definicje. Różne nie znaczy sprzeczne [w:] Wczesna interwencja w logopedii, red. J.J. Błeszyński, D. Baczała, Harmonia Universlias, Gdańsk 2015, s. 31-42.

${ }^{3}$ Ibidem.

4 R.J. Simeonsson, Early childchood Intervention, "Infants and Young Children" 2000, 12, s. 4-9. 
częścią rodziny, a wszystko, czego doświadczają poszczególni jej członkowie, wpływa na jej funkcjonowanie jako całości. W niej człowiek znajduje oparcie i siłę, a więc wymaga ona wsparcia w trudnej drodze towarzyszenia bliskiej osobie w procesie diagnostyczno-terapeutycznym. W trakcie diagnozy i terapii dziecka, zwłaszcza małego, konieczna jest obecność rodziców, którym trzeba przekazać informacje na temat występujących nieprawidłowości, ale także mocnych stron dziecka, udzielić konkretnych wskazówek terapeutycznych oraz wsparcia psychicznego.

Idea wczesnej interwencji logopedycznej wyrasta z potwierdzonej badaniami tezy o plastyczności mózgu i jego zdolności do zmian pod wpływem działania bodźców ze środowiska ${ }^{5}$. Zdolność do przeorganizowania komórek nerwowych dotyczy zarówno dzieci (plastyczność rozwojowa), jak i osób dorosłych (plastyczność kompensacyjna). Michael Gazzaniga podkreśla, że choć „wzór połączeń neuronalnych powstaje pod kontrolą genetyczną, bodźce zewnętrzne - pochodzące ze środowiska i z ćwiczenia - również wpływają na wzrost neuronów i tworzenie połączeń" ${ }^{\prime \prime}$. Zdolność do naprawy uszkodzeń układu nerwowego zmniejsza się wraz z wiekiem ${ }^{7}$. Badacze zwracają uwagę na istnienie okresów wrażliwych (sensytywnych), czyli takich, w których występuje największa podatność mózgu na działanie bodźców zewnętrznych, pod wpływem których może dojść do zmian w ośrodkowym układzie nerwowym (OUN) ${ }^{8}$. Podjęcie działań w tym czasie zwiększa szansę na prawidłowy rozwój i optymalizuje efekty terapii.

${ }^{5}$ H. Als i in., Early experience alters brain function and structure, „Pediatrics” 2004, 113(4), s. 846-857; M. Kossut, Synapsy i plastyczność mózgu, http:/ / fundacjarozwojunauki. pl/res/Tom1/Nauka\%20swiatowa\%20i\%20polska\%5B1\%5D.Rozdzial\%2009.pdf [dostęp: 19.09.2016].

${ }^{6}$ M.S. Gazzaniga, Kto tu rządzi - ja czy mój mózg? Neuronauka a istnienie wolnej woli, Smak słowa, Sopot 2013, s. 25.

7 J. Doroszewska, Neurogeneza i plastyczność synaptyczna ośrodkowego układu nerwowego, [w:] Apoptoza w chorobach ośrodkowego układu nerwowego, red. W. Kozubski, J. Doroszewska, Czelej, Lublin 2008, s. 45-64.

8 S.J. Blakemore, U. Frith, Jak uczy się mózg, Wydawnictwo UJ, Kraków 2008. 
Wczesna interwencja przynosi wymierne korzyści osobie, która w niej uczestniczy, poprawiając jakość jej egzystencji, dając szansę samorealizacji i godnego życia. Daje także realne korzyści ekonomiczne całemu społeczeństwu - zmniejszając wydatki państwa na renty czy zasiłki chorobowe. Należy tez pamiętać o względach natury etycznej, uzasadniających podjęcie działań z zakresu wczesnej interwencji.

\section{Procedury postępowania logopedycznego}

Wśród procedur postępowania logopedycznego Stanisław Grabias wymienia: diagnozowanie, programowanie terapii i realizację procesu terapeutycznego ${ }^{9}$. Zgodnie $\mathrm{z}$ ujęciem proponowanym przez autora diagnozowanie to deskrypcja, czyli opis sprawności interakcyjnych takich jak: wymowa, język, struktury pojęciowe, dialog i wypowiedzi narracyjne, a także interpretacja wyników badań specjalistycznych oraz danych z wywiadu rodzinnego. Opis i interpretacja symptomów zaburzeń mowy pozwalają na postawienie diagnozy nozologicznej oraz wykluczenie innych rozpoznań, w ramach tzw. diagnozy różnicowej. Rejestracja i rzetelne opisanie objawów zaburzeń w zakresie komunikacji językowej stanowi podstawę programowania procesu terapeutycznego oraz samej terapii. Programując ją, określa się cele postępowania logopedycznego, jego strategie i metody. Realizacja terapii wymaga zastosowania odpowiednich środków i pomocy, a także cyklicznej oceny uzyskiwanych efektów po to, by kontynuować zaplanowane działania lub dokonać ich korekty. Diagnozowanie, programowanie terapii, a także jej prowadzenie, to procedury obecne także we wczesnej interwencji logopedycznej, skierowanej do najmłodszych pacjentów od momentu narodzin, odpowiednio zmodyfikowane ze względu na możliwości rozwojowe dzieci w tym wieku.

${ }^{9}$ S. Grabias, Postępowanie logopedyczne. Standardy terapii, [w:] Logopedia. Standardy postępowania logopedycznego. Podręcznik akademicki, red. S. Grabias, J. Panasiuk, T. Woźniak, Wydawnictwo UMCS, Lublin 2015, s. 13-35. 


\section{Schemat diagnozy logopedycznej noworodków i niemowląt}

Diagnozę logopedyczną noworodka i niemowlęcia przeprowadza się z zachowaniem ogólnych reguł obowiązujących w postępowaniu diagnostycznym. Składają się na nią wszystkie elementy niezbędne do postawienia rozpoznania logopedycznego, a więc:

- wywiad z rodzicami,

- analiza dokumentacji specjalistycznej (przede wszystkim wyników badań neonatologicznych, neurologicznych, laryngologicznych, audiologicznych, ocena psychologa, fizjoterapeuty, rehabilitanta oraz pozostałych specjalistów w zależności od potrzeb),

- badanie logopedyczne.

Celem wywiadu jest uzyskanie informacji o przebiegu ciąży i porodu, stanie dziecka po urodzeniu, a także obserwowanych przez rodziców nieprawidłowościach związanych ze sposobem jego oddychania, reagowania na dźwięki z otoczenia, stanem napięcia mięśniowego czy trudnościami podczas karmienia. Rozmowa z rodzicami noworodków i niemowląt $\mathrm{z}$ wadami genetycznymi, uszkodzeniami OUN, uszkodzeniami narządów zmysłów, poważnymi uszkodzeniami strukturalnymi obwodowego narządu mowy (rozszczep wargi i/lub podniebienia) czy też skrajnie niedojrzałych wcześniaków wymaga szczególnego taktu i subtelności. Przyjście na świat dziecka z wadami i zaburzeniami rozwojowymi lub zagrożonego wystąpieniem patologii to traumatyczne przeżycie, dlatego rodzice potrzebują czasu na przystosowanie się do nowej sytuacji. Częstą reakcją na taką wiadomość jest rozpacz, poczucie utraty oczekiwanego, zdrowego dziecka, a w konsekwencji bezradność oraz apatia. Zdarza się niechęć do podjęcia leczenia i terapii, ze względu na brak wiary $\mathrm{w}$ ich skuteczność. U części rodziców występuje reakcja zaprzeczenia i wyparcia problemu. Mogą nie chcieć lub nie umieć współpracować z personelem medycznym, psychologiem czy logopedą, dlatego dużo zależy od specjalistów prowadzących rozmowę, ich wrażliwości, poczucia empatii, ale przede wszyst- 
kim profesjonalizmu. Prawidłowo przeprowadzony wywiad dostarcza cennych informacji na temat funkcjonowania pacjenta. Uwagi rodziców o występujących nieprawidłowościach i zachowaniach dziecka, które obserwują podczas opieki nad noworodkiem i niemowlęciem, znacząco wpływają na trafność diagnozy i jakość udzielanej pomocy.

W diagnozowaniu, leczeniu i terapii dziecka niepełnosprawnego lub znajdującego się w grupie ryzyka istotną rolą jest współdziałanie lekarzy, psychologów, rehabilitantów, logopedów itp. Problemy diagnozowanych osób mogą manifestować się w różnych sferach, nakładając się na siebie i potęgując niekorzystne skutki, dlatego ich właściwe rozpoznanie, a potem eliminacja wymaga działań całego zespołu leczniczo-terapeutycznego. Staranna analiza dokumentacji medycznej i psychologicznej pomaga logopedzie w postawieniu diagnozy - przede wszystkim w określeniu patomechanizmu i przyczyny obserwowanych zaburzeń/nieprawidłowości oraz zaplanowaniu procesu terapeutycznego.

Badanie logopedyczne noworodka i niemowlęcia polega na ocenie czynności, które poprzedzają pojawienie się języka. Obejmuje zarówno czynności biologiczne, jak i pierwsze zachowania o charakterze społecznym, służące porozumiewaniu się z otoczeniem, przekazywaniu intencji w sposób pozawerbalny. Trzeba pamiętać, że komunikacyjna sprawność pragmatyczna wyprzedza pojawienie się sprawności systemowej, sytuacyjnej i społecznej10. Rozwój komunikacji w okresie prelingwalnym odbywa się za pomocą swoistego dialogu, prowadzonego przez dorosłych przy użyciu środków językowych i niejęzykowych, a pozawerbalnych przez dziecko. Taki rodzaj komunikowania się nosi nazwę kontaktów konwersacjopodobnych ${ }^{11}$.

10 S. Grabias, Pojęcie sprawności językowej a praktyka logopedyczna, "Logopedia” 1990, tom 17, s. 51-63.

11 M. Kielar-Turska, M. Białecka-Pikul, Wczesne dzieciństwo, [w:] Psychologia rozwoju człowieka. Charakterystyka okresów życia człowieka, red. B. Harwas-Napierała, J. Trempała, Wydawnictwo Naukowe PWN, Warszawa 2006, s. 47-82. 
Przeprowadzając badanie logopedyczne $\mathrm{w}$ ramach wczesnej interwencji, należy różnicować objawy patologiczne od tych związanych z niedojrzałością układu nerwowego, która jest charakterystyczna dla wcześniaków ${ }^{12}$. Dlatego przy ocenie dziecka urodzonego przedwcześnie istotne jest uwzględnianie tzw. wieku skorygowanego, czyli wieku metrykalnego pomniejszonego o tygodnie brakujące do terminu porodu ${ }^{13}$.

W badaniu logopedycznym dziecka do pierwszego roku życia oceniane są:

1. Czynności prymarne, takie jak odruchy ustno-twarzowe, sposób przyjmowania pokarmów, sposób oddychania. Podczas badania logopeda ocenia odruchy: otwierania/zwierania ust, żuchwowy, ryjkowy, lizania, szukania, kąsania, ssania, połykania, zwracania/ /wymiotny, żucia. Dokładny opis sposobu wyzwalania i oceny poszczególnych odruchów znaleźć można $\mathrm{w}$ publikacjach Elżbiety Stecko, Swietłany Masgutowej i Anny Regner ${ }^{14}$. Przeprowadzając badanie logopedyczne dziecka urodzonego przedwcześnie, należy wziąć pod uwagę fakt, że efektywne ssanie pojawia się po 32. tygodniu życia płodowego, dlatego odruch ssania nie będzie występował u skrajnych wcześniaków ${ }^{15}$. Badanie odruchów, a także sposób, $\mathrm{w}$ jaki dziecko radzi sobie z przyjmowaniem pokarmów pozwalają jednocześnie na wysunięcie wniosków dotyczących sprawności aparatu artykulacyjnego. Ocena sposobu oddychania dokonywana przez logopedę dotyczy przede wszystkim toru oddechowego.

12 P. Zawitkowski, Wczesna stymulacja rozwoju dzieci urodzonych przedwcześnie, [w:] Noworodek przedwcześnie urodzony - pierwsze lata życia, red. M.K. Kornacka, Wydawnictwo Lekarskie PZWL, Warszawa 2003, s. 68-86.; Z. Kołakowska, Alternatywy wczesnej interwencji, „Postępy w Neonatologii” 1999, tom 10, s. 358-363.

13 B. Stoińska, A. Montgomery, Model i rola poradni wczesnej oceny rozwoju dziecka, [w:] Noworodek przedwcześnie urodzony - pierwsze lata życia, red. M.K. Kornacka, Wydawnictwo Lekarskie PZWL, Warszawa 2003, s.21-32

${ }^{14}$ E. Stecko, Logopedia małego dziecka, Wydawnictwo ES, Legionowo 2013; S. Masgutowa, A. Regner, Rozwój mowy w świetle integracji sensomotorycznej, Wydawnictwo Continuo, Wrocław 2009.

15 B. Cieślak-Osik, I. Staniak, M.K. Kornacka, Metody wczesnej stymulacji rozwojowej oraz wspomaganie terapii noworodka przedwcześnie urodzonego. „Klinika Pediatryczna" 2007, vol. 15, nr 1, s. 53-58. 
2. Budowa narządów artykulacyjnych: języka, także wędzidełka podjęzykowego, warg, podniebienia twardego i miękkiego, żuchwy. Przy ocenie należy brać pod uwage typowe dla dziecka w tym wieku cechy morfologiczne i funkcjonalne aparatu artykulacyjnego, takie jak np. fizjologiczne tyłożuchwie (dotylne ustawienie żuchwy w stosunku do szczęki) czy trzewny/niemowlęcy sposób połykania, z językiem pomiędzy wałami dziąsłowymi. Należy także uwzględnić obecne u niektórych odbiorców wczesnej interwencji wcześniaków - zmiany w morfologii aparatu artykulacyjnego. Tzw. gotyckie podniebienie występujące $\mathrm{w}$ chwili narodzin u niektórych dzieci urodzonych przedwcześnie nie ma charakteru patologicznego, ale jest konsekwencją zbyt krótkiego czasu przeznaczonego na rozwój podniebienia $\mathrm{w}$ okresie płodowym ${ }^{16}$. Podczas badania narządów artykulacyjnych dokonuje się także oceny napięcia mięśniowego języka, warg, policzków, którą weryfikuje się z informacjami na temat stopnia dojrzałości i dystrybucji napięcia mięśniowego w całym ciele uzyskanymi od neurologa, rehabilitanta czy fizjoterapeuty.

3. Wrażliwość twarzy na dotyk. Nadwrażliwość objawiająca się wygórowanymi reakcjami (zdecydowane kręcenie głową, nadmierne pobudzenie ruchowe, płacz) występuje np. u dzieci, które przyszły na świat drogą cesarskiego cięcia. Najbardziej niedojrzałe wcześniaki, a także te po zabiegach operacyjnych, często nie tolerują nawet bardzo delikatnego dotyku, co należy uwzględnić w procedurze diagnostycznej ${ }^{17}$.

4. Reakcje słuchowe na dźwięki z otoczenia, w tym dźwięki mowy (obecne już w okresie płodowym). Pożądaną reakcją dziecka jest chwilowa przerwa w ssaniu podczas karmienia albo wstrzymanie ruchów ciała, a także poszukiwanie źródła dźwięku poprzez odwracanie głowy w kierunku, z którego on dochodzi (ta ostatnia 2008.

${ }^{16}$ C. Amiel-Tison, Neurologia perinatalna, Elsevier Urban\&Partner, Wrocław

17 J. Świetliński, Dobry dotyk, [w:] Neonatologia i opieka nad noworodkiem, red. J. Świetliński, Wydawnictwo Lekarskie PZWL, Warszawa 2016, s. 331-335. 
reakcja pojawia się około piątego miesiąca życia - dalej m.ż.) ${ }^{18}$. Reakcją na głos znanych niemowlęciu osób (przede wszystkim rodziców) jest uśmiech, radosne pobudzenie, ożywienie. Warto zaznaczyć, że w Polsce od 2002 r. przeprowadza się powszechne przesiewowe badania słuchu noworodków, które są podstawowym źródłem informacji o stanie słuchu dziecka po porodzie. Ponieważ do uszkodzeń słuchu może dojść na wszystkich etapach rozwoju (a więc już po tych badaniach przesiewowych) bardzo istotna jest kontrola reakcji niemowlęcia na bodźce słuchowe, dokonywana podczas badania logopedycznego.

5. Wstępna faza rozwoju mowy obejmująca: zachowania symptomatyczne, takie jak krzyk, płacz (od chwili narodzin), głużenie (pojawiające około 2. m.ż.) i gaworzenie (pojawiające się około 6. m.ż.) oraz początki zachowań językowych - pierwsze wyrazy (najczęściej nazwy osób z najbliższego otoczenia), które pojawiają się u prawidłowo rozwijającego się dziecka pod koniec okresu niemowlęcego.

6. Kontakt wzrokowy oraz wspólne pole uwagi, które zaczyna kształtować się około 9. m.ż. ${ }^{19}$. Brak kontaktu wzrokowego oraz brak wspólnego pola uwagi mogą być wczesnym objawem przyszłych zaburzeń mowy związanych z autyzmem, upośledzeniem rozwoju umysłowego, niedosłuchem/głuchotą. Umiejętność skupiania wzroku na twarzy dorosłego rozwija się już u noworodka. Ocenie podlega także uśmiech społeczny, który pojawia się u dziecka około 3. m.ż. Zdrowe dziecko po 2. m.ż. reaguje mimiką na twarz osoby dorosłej i śledzi ją wzrokiem ${ }^{20}$.

7. Gesty, zwłaszcza gest wskazywania palcem, odgrywający ważną rolę komunikacyjną, a pojawiający się około 9. m.ż. ${ }^{21}$. Za jego pomocą niemowlę wyraża prośbę o coś, wskazuje lub pokazuje przedmiot.

${ }^{18}$ J. Cieszyńska, M. Korendo, Wczesna interwencja terapeutyczna. Stymulacja rozwoju dziecka od noworodka do 6. roku życia. Wydawnictwo Edukacyjne, Kraków 2008.

19 Ibidem.

${ }^{20}$ Ibidem.

${ }^{21}$ Ibidem. 
8. Rozumienie przez dziecko prostych wypowiedzi otoczenia. Oceny dokonuje się poprzez polecenia i pytania typu: pokaż jaki jesteś duży, daj mamie buziaka, daj grzechotkę, pokaż jaki smaczny jest sok, pokaż gdzie jest tata, pokaż gdzie masz ucho (dotyczy dzieci w drugim półroczu życia).

9. Umiejętność naśladowania, która stanowi podstawę uczenia się, w tym nabywania zdolności komunikacyjnych. U niemowląt (ok. 8-9. m.ż.) bada się zdolność naśladowania gestów np. gestu na pożegnanie czy negacji, a także umiejętność odtwarzania ruchów takich jak np. wyciąganie rąk do góry, poklepywanie się/głaskanie po brzuchu, klaskanie (bicie brawa), przesyłanie całusów.

\section{Wybrane narzędzia służące ocenie logopedycznej dzieci do pierwszego roku życia}

Procedura diagnostyczna wymaga zastosowania odpowiednich narzędzi. Są nimi różnego rodzaju karty badania, testy, skale, kwestionariusze. Propozycję narzędzia do wczesnej oceny logopedycznej dziecka od okresu niemowlęcego do trzeciego roku życia przedstawili Izabela Bogudzińska i Tomasz Woźniak ${ }^{22}$. Kwestionariusz wczesnej diagnozy logopedycznej (KWDL) wymienionych autorów składa się z trzech części przeznaczonych odpowiednio dla dzieci w przedziałach wiekowych: a) od 1. do 12. m.ż.; b) od 13. do 24. m.ż.; c) od 25. Do 36. m.ż.23. Część poświęcona diagnozie logopedycznej niemowlęcia obejmuje ocenę czterech obszarów: odruchy, mowa i rozumienie, percepcja, a także motoryka duża i mała. W ich obrębie wyszczególniono różne reakcje i zachowania dziecka. Przy każdej

${ }^{22}$ I. Bogudzińska, T. Woźniak, Kwestionariusz wczesnej diagnozy logopedycznej (KWDL) - propozycja diagnozy dzieci w przedziale wieku od 6. do 36. miesiąca życia. „Logopedia" 2013, t. 42, s. 203-214.

${ }^{23} \mathrm{~W}$ tytule artykułu prezentującego narzędzie autorzy użyli sformułowania „(...) propozycja diagnozy dzieci w przedziale wieku od 6. do 36. miesiąca życia” (s. 203), natomiast w tekście przedział wiekowy został określony jako „(...) od 1. do 12. miesiąca życia" (s. 205). 
ocenianej pozycji znajduje się miejsce pozwalające na wpisanie czy dana reakcja bądź zachowanie występuje oraz na ewentualne uwagi.

W pierwszym obszarze autorzy zalecają badanie następujących odruchów: otwierania ust, ssania, szukania, kąsania, ryjkowego, żuchwowego, wymiotnego oraz żucia. Przy każdym zaznaczono czas, do którego występuje on u prawidłowo rozwijającego się niemowlęcia. Przetrwały odruch (obecny poza podanymi granicami czasowymi) może świadczyć o istniejących nieprawidłowościach.

Na badanie w obszarze obejmującym mowę i rozumienie składa się ocena: głużenia, gaworzenia, głośnego śmiechu, sygnałów dźwiękowych w formie sygnałów znaczących, reakcji na imię, inicjacji dialogu przez gaworzenie, poszukiwania wzrokiem osoby lub przedmiotu w reakcji na zapytanie, wykonania/rozumienia prostych poleceń, sposobu uczestniczenia w zabawach charakterystycznych dla okresu niemowlęcego typu „a ku-ku”, wypowiadanych samogłosek i spółgłosek.

Przy badaniu percepcji bierze się pod uwagę: reakcję na ostre światło oraz głośne odgłosy, zatrzymanie wzroku na twarzy osoby dorosłej i jej śledzenie, uśmiech społeczny, poszukiwanie źródła dźwięku, spoglądanie na przedmiot, który upadł, naśladowanie czynności dorosłego, wskazywanie palcem, zainteresowanie odbiciem w lustrze.

Badanie motoryki malej i dużej polega na ocenie pojawiających się w odpowiednim czasie określonych umiejętności ruchowych, takich jak: podnoszenie i utrzymywanie głowy, zabawy rękoma, chwytanie i przekładanie przedmiotów z ręki do reki, obracanie się z pleców na brzuch, siadanie, raczkowanie, chodzenie.

Uzupełnieniem danych z KWDL jest badanie budowy i ruchomości aparatu artykulacyjnego, sposobu oddychania, sposobu przyjmowania pokarmów oraz ankieta z rodzicami dziecka.

Narzędziem pozwalającym na ocenę umiejętności prelingwalnych dziecka są także karty diagnozy neurologopedycznej niemowlęcia od narodzin do 12. m.ż. Marzeny Machoś24. Kwestionariusz

${ }_{24}$ M. Machoś, Diagnoza neurologopedyczna niemowlęcia od 0 do 12 miesiąca życia. Ocena odruchów ze sfery orofacjalnej oraz umiejętności istotnych dla rozwoju mowy. Wydawnictwo Ergo Sum, Bytom 2011. 
składa się z trzech części. Pierwsza obejmuje dane z wywiadu z rodzicami, druga służy ocenie budowy narządów artykulacyjnych, sposobu oddychania, przyjmowania pokarmów i picia, odruchów ustno-twarzowych, wrażliwości na dotyk, trzecia jest pomocna w ocenie przedjęzykowych zachowań dziecka, istotnych dla rozwoju mowy. Autorka zwraca uwagę na konieczność uwzględnienia w ocenie pozycji niemowlęcia podczas karmienia, sekwencyjności ssania. Ocenę odruchów poza wymienionymi przez I. Bogudzińską i T. Woźniaka poszerza o badanie odruchu Babkina i odruchu akustyczno-twarzowego. Przy ocenie prelingwalnych aspektów komunikacyjnych koncentruje się na: krzyku, płaczu, głużeniu, gaworzeniu, pierwszych słowach, skupianiu wzroku niemowlęcia na twarzy osoby dorosłej, fiksowaniu wzroku na przedmiocie, reakcjach słuchowych na dźwięki z otoczenia oraz na geście wskazywania palcem.

W diagnozie logopedycznej niemowląt specjaliści mogą skorzystać również z arkuszy obserwacyjnych opracowanych w kanadyjskim Centrum Hanen ${ }^{25}$. Wśród dwóch pierwszych etapów rozwoju mowy wyodrębnionych przez terapeutów tej organizacji, podaje się "stadium odkrywania świata” (od narodzin do 8. m.ż) oraz „stadium początków komunikacji" (od 8. do 13. m.ż.) ${ }^{26}$. W arkuszu obserwacyjnym dzieci z wymienionych okresów rozwoju mowy zwraca się uwagę na cele i częstotliwość sygnałów komunikacyjnych danego rodzaju (część A), a także sposób ich wysyłania (część B) oraz sposób uczestniczenia dziecka w interakcjach (część C).

W części A arkusza wylicza się następujące powody komunikowania się dziecka z otoczeniem: protest, prośba o przedmiot lub wykonanie czynności, prośba o uczestnictwo w zabawie, prośba o uwagę, reakcja na słowa osoby dorosłej, prośba o pocieszenie,

${ }^{25}$ Centrum Hanen jest kanadyjską organizacją pożytku publicznego prowadzącą szkolenia z zakresu rozwoju i zaburzeń mowy przeznaczone dla logopedów i innych specjalistów, a także rodziców dzieci z problemami w zakresie komunikacji językowej,

26 E. Weitzman, J. Greenberg, Razem uczymy się mówić. Przewodnik dotyczacy wspomagania rozwoju językowego dzieci dla opiekunów i nauczycieli przedszkoli, Wydawnictwo Harmonia, Gdańsk 2014. 
popisywanie się lub zwracanie na siebie uwagi, zwracanie uwagi na ludzi, rzeczy oraz zdarzenia, opisywanie rzeczywistości przy użyciu pierwszych pojawiających się słów, wykorzystywanie obrazka lub znaku, prośba o informację poprzez stosowanie intonacji pytającej. Osoba dokonująca oceny określa częstotliwość poszczególnych zachowań komunikacyjnych, zaznaczając, czy występują one często, czasami, rzadko, nigdy.

Część B pozwala na określenie sposobów przekazywania intencji komunikacyjnych. W stadium odkrywania świata są nimi: płacz, spoglądanie na osobę dorosłą, uśmiech, wydawanie dźwięków zbliżonych do samogłosek i spółgłosek, zmiana natężenia i wysokości głosu, ruchy ciała, zmiana wyrazu twarzy, głośny śmiech, wyciąganie rak. W stadium początków komunikacji do sposobów wyrażania intencji komunikacyjnych zalicza się: spoglądanie na osobę, wskazywanie, gestykulację typu machanie ręką, potrząsanie głową, pokazywanie, za pomocą którego dziecko próbuje przekazać to, co chciałoby powiedzieć, połączenie kontaktu wzrokowego, wydawania dźwięków i wskazywania, wydawanie dźwięków, posiadających znaczenie oraz wypowiadanie pojedynczych słów. $\mathrm{Na}$ marginesie należy dodać, że dzieci z niepełnosprawnością złożoną, wielozakresową mogą przekazywać intencje komunikacyjne w sposób nietypowy, ważne zatem, aby umieć je rozpoznawać i traktować jako potencjalnie komunikacyjne, co podkreśla Walter Strassmeier ${ }^{27}$.

W części C badający ocenia sposoby uczestniczenia dziecka w interakcjach, spośród których wymienione zostały: wydawanie dźwięków mających na celu kolejną wymianę wypowiedzi, wyrażanie zainteresowania uwagą osoby dorosłej, łatwość, z jaką dziecko daje się zaangażować w zabawy typu "a ku-ku”, inicjowanie zabaw typu "a ku-ku”, zwracanie uwagi dziecka na siebie i na przedmioty znajdujące się $\mathrm{w}$ jego otoczeniu, jednoczesne wyko-

27 W. Strassmeier, przekład Magdalena Wojdak-Piatkowska, Interwencja wczesnodziecięca. 260 praktycznych ćwiczeń dla matych dzieci z trudnościami w rozwoju. Harmonia Universalis, Gdańsk 2014. 
rzystywanie kontaktu wzrokowego, dźwięków, gestów i czynności oraz wchodzenie $\mathrm{w}$ interakcje $\mathrm{z}$ dorosłym $\mathrm{z}$ wykorzystaniem zabawek.

\section{Podsumowanie}

W artykule zaprezentowano ogólny schemat diagnozy logopedycznej noworodka i niemowlęcia, a także przybliżono wybrane narzędzia, które mogą być pomocne w ocenie prelingwalnego etapu rozwoju mowy. Każdorazowo trzeba dostosowywać czynności diagnostyczne do potrzeb i możliwości poszczególnych pacjentów. Diagnoza małego dziecka wymaga wyjątkowej uwagi, czasu i staranności. Konieczne jest uwzględnienie prawidłowości rozwojowych dzieci $\mathrm{w}$ tym wieku, trzeba też pamiętać, że nie wszystkie manifestowane objawy świadczą o patologii, część może wynikać z braku dojrzałości układu nerwowego. Badanie logopedyczne nie powinno skupiać się wyłącznie na nieprawidłowościach, ważne aby wskazywało także te sfery, w których niemowlę funkcjonuje prawidłowo. Wszystkie próby oceniające dziecko należy przeprowadzać zgodnie z zasadą zachowania maksymalnego komfortu małego pacjenta, a z wynikami diagnozy logopedycznej powinni być szczegółowo zapoznani jego rodzice. Trafne rozpoznanie problemów dziecka stanowi podstawę zaleceń terapeutycznych i realizacji programu usprawniającego zaburzone funkcje mowy oraz stymulującego umiejętności komunikacyjne.

\section{Bibliografia}

Als H. i in., Early experience alters brain function and structure, „Pediatrics” 2004, 113(4).

Amiel-Tison C., Neurologia perinatalna, Elsevier Urban\&Partner, Wrocław 2008.

Blakemore S.J., Frith U., Jak uczy się mózg, Wydawnictwo UJ, Kraków 2008.

Błeszyński J.J., Wczesna interwencja - różne podejścia, ujęcia, definicje. Różne nie znaczy sprzeczne, [w:] Wczesna interwencja w logopedii, red. J.J. Błeszyński, D. Baczała, Harmonia Universlias, Gdańsk 2015. 
Bogudzińska I., Woźniak T., Kwestionariusz wczesnej diagnozy logopedycznej (KWDL) propozycja diagnozy dzieci w przedziale wieku od 6. do 36. miesiaca życia. „Logopedia" 2013, tom 42.

Cieszyńska J., Korendo M., Wczesna interwencja terapeutyczna. Stymulacja rozwoju dziecka od noworodka do 6. roku życia. Wydawnictwo Edukacyjne, Kraków 2008.

Cieślak-Osik B., Staniak I., Kornacka M.K., Metody wczesnej stymulacji rozwojowej oraz wspomaganie terapii noworodka przedwcześnie urodzonego. „Klinika Pediatryczna” 2007, vol. 15, nr 1 .

Doroszewska J., Neurogeneza i plastyczność synaptyczna ośrodkowego układu nerwowego, [w:] Apoptoza w chorobach ośrodkowego układu nerwowego, red. W. Kozubski, J. Doroszewska, Czelej, Lublin 2008.

Gazzaniga M.S., Kto tu rzadzi - ja czy mój mózg? Neuronauka a istnienie wolnej woli, Smak słowa, Sopot 2013.

Grabias S. Postępowanie logopedyczne. Standardy terapii, [w:] Logopedia. Standardy postępowania logopedycznego. Podręcznik akademicki, red. S. Grabias, J. Panasiuk, T. Woźniak, Wydawnictwo UMCS, Lublin 2015.

Grabias S., Pojęcie sprawności językowej a praktyka logopedyczna, „Logopedia” 1990, tom 17.

Kielar-Turska M., Białecka-Pikul M., Wczesne dzieciństwo, [w:] Psychologia rozwoju człowieka. Charakterystyka okresów życia cztowieka, red. B. Harwas-Napierała, J. Trempała, Wydawnictwo Naukowe PWN, Warszawa 2006.

Kołakowska Z, Alternatywy wczesnej interwencji, „Postępy w Neonatologii” 1999, tom 10.

Kossut M., Synapsy i plastyczność mózgu, http:/ fundacjarozwojunauki.pl/res/Tom1 /Nauka\%20swiatowa\%20i\%20polska\%5B1\%5D Rozdzial\%2009.pdf [dostęp: 19.09.2016].

Machoś M., Diagnoza neurologopedyczna niemowlęcia od 0 do 12 miesiaca życia. Ocena odruchów ze sfery orofacjalnej oraz umiejętności istotnych dla rozwoju mowy, Wydawnictwo Ergo Sum, Bytom 2011.

Masgutowa S., Regner A., Rozwój mowy w świetle integracji sensomotorycznej, Wydawnictwo Continuo, Wrocław 2009.

Pluta-Wojciechowska D., Wczesna interwencja logopedyczna - moda, postulat czy konieczność, [w:] Wczesna interwencja w logopedii, red. J.J. Błeszyński, D. Baczała, Harmonia Universlias, Gdańsk 2015.

Simeonsson R.J., Early childchood Intervention, „Infants and Young Children” 2000, 12.

Stecko E., Logopedia małego dziecka, Wydawnictwo ES, Legionowo 2013.

Stoińska B., Montgomery A., Model i rola poradni wczesnej oceny rozwoju dziecka, [w:] Noworodek przedwcześnie urodzony - pierwsze lata życia, red. M.K. Kornacka, Wydawnictwo Lekarskie PZWL, Warszawa 2003.

Strassmeier W., Interwencja wczesnodziecięca. 260 praktycznych ćwiczeń dla matych dzieci z trudnościami w rozwoju, Harmonia Universalis, Gdańsk 2014. 
Świetliński J., Dobry dotyk, [w:] Neonatologia i opieka nad noworodkiem, red. J. Świetliński, Wydawnictwo Lekarskie PZWL, Warszawa 2016.

Wczesna, wielospecjalistyczna, kompleksowa, skoordynowana i ciagta pomoc dziecku zagrożonemu niepetnosprawnością lub niepetnosprawnemu oraz jego rodzinie, https:/ / www. nfz.rzeszow.pl/files/dokumenty/63_2005_zal.pdf [dostęp 19.09. 2016.].

Weitzman E., Greenberg J., Razem uczymy się mówić. Przewodnik dotyczacy wspomagania rozwoju jezzykowego dzieci dla opiekunów i nauczycieli przedszkoli, Wydawnictwo Harmonia, Gdańsk 2014.

Zawitkowski P., Wczesna stymulacja rozwoju dzieci urodzonych przedwcześnie, [w:] Noworodek przedwcześnie urodzony - pierwsze lata życia, red. M.K. Kornacka, Wydawnictwo Lekarskie PZWL, Warszawa 2003. 